\title{
Interaction between obesity-susceptibility loci in chromosome regions 2p25-p24 and 13q13-q21
}

\author{
Chuanhui Dong ${ }^{1}$, Wei-Dong $\mathrm{Li}^{1}$, Ding $\mathrm{Li}^{1}$ and $\mathrm{R}$ Arlen Price ${ }^{*, 1}$ \\ ${ }^{1}$ Center for Neurobiology and Behavior, Department of Psychiatry, University of Pennsylvania, Philadelphia, PA, USA
}

One of the chief complexities of genetic influences on human obesity appears to be gene-gene interactions. Here, we employed model-free approaches to look for gene-gene interaction effects in human obesity using genome scan data from 260 European American families. We found consistent evidence for statistical interaction between 2p25-p24 (18-38 cM) and 13q13-q21 (26-47 cM). For discrete traits, the positive correlations were significant at $P<0.0001$ ( $P \leq 0.0023$ after correction for multiple tests) in both IBD-based and NPL-based analyses for $B M I \geq 40 \mathrm{~kg} / \mathrm{m}^{2}$. Other analytic approaches gave consistent, supportive results. For quantitative traits, interaction effects were significant for $B M I(P=0.0012)$, percent fat $(P=0.0265)$ and waist circumference $(P=0.0023)$ in a Haseman-Elston regression model, and for BMI $(P=0.0043)$ in variance component analysis. Our findings suggest that obesity-susceptibility loci in chromosome regions 2p25-p24 and 13q13-21 may interact to influence extreme human obesity. The identification of gene-gene interactions may prove crucial to understanding the contributions of genes, which, by themselves, have relatively small effects on obesity susceptibility and resistance.

European Journal of Human Genetics (2005) 13, 102-108. doi:10.1038/sj.ejhg.5201292

Published online 6 October 2004

Keywords: linkage; correlation; regression; variance components; interaction; obesity

\section{Introduction}

Obesity is one of the top public health problems in the world and is associated with increased risk for type II diabetes mellitus, hypertension, cardiovascular diseases and some cancers. ${ }^{1-5}$ Family, twin and adoption studies of human obesity have demonstrated that a substantial portion of family variance is genetic in origin, with up to one-third of the genetic variance due to nonadditive factors. ${ }^{6-14}$ Many single genes have been examined through association studies, and multiple quantitative trait loci have been identified through genome scans. However, only a few, mostly very rare, monogenetic forms of human obesity have been detected. ${ }^{15}$ The pattern of inheritance of obesity and the rarity of mutations in known major genes

*Correspondence: $\operatorname{Dr} \mathrm{R}$ Arlen Price, Center for Neurobiology and Behavior, University of Pennsylvania, 415 Curie Blvd., CRB-105, Philadelphia, PA 19104-6140, USA. Tel: + 1215898 0214; Fax: + 1215573 2041; E-mail: arlen@bgl.psycha.upenn.edu

Received 28 April 2004; revised 27 July 2004; accepted 13 August 2004 strongly suggest a multigenic inheritance with individual gene effects mediated by genomic background and environmental influences.

A number of linkage studies, including $\sim 30$ human genome scans, have reported about 70 genetic loci linked with obesity in humans. ${ }^{15}$ The results vary substantially across studies and 'replications' (reported linkages in the same region) have been limited, including 2p22, 3q27, $6 \mathrm{p} 21,10 \mathrm{p} 12,11 \mathrm{q} 23-11 \mathrm{q} 24,17 \mathrm{p} 12$ and 18q21. A common aspect of these studies is that most were based on small samples, and only a small number of results reached a genome-wide level of significance. Apart from these issues of power and significance, the generally weak results may be due to the overly simplified models of inheritance we and others have employed.

Several lines of evidence suggest epistatic effects on obesity may be common. Consistent differences in estimates of genetic heritability of obesity between family and twin studies indicate that about one-third of the heritable variance may be nonadditive. ${ }^{16}$ Several animal models give 
clear evidence of gene-gene interactions. ${ }^{17-19}$ Molecular genetic studies also demonstrate that some genes are needed to mediate the effects of others. ${ }^{20}$

Studies of several complex traits have identified susceptibility loci by allowing for gene-gene interaction in the linkage analyses, including diabetes, ${ }^{21}$ asthma, ${ }^{22}$ psoria$\operatorname{sis}^{23}$ and systemic lupus erythematosus. ${ }^{24}$ We have reported a potential epistatic effect between chromosome 10 and $20 \mathrm{q}$ in the linkage analysis similar to those employed in the current paper. ${ }^{14}$

In the present study, we extended our analyses to look for potential interacting genetic loci among several regions linked to obesity phenotypes based on our recently completed second-generation genome-wide linkage study in 260 European American families segregating extreme obesity and normal weight. ${ }^{25}$

\section{Subjects and methods Families}

This study included 260 European American families ascertained nationwide in a genetic study of obesity at the University of Pennsylvania. The recruitment processes have been described previously. ${ }^{26,27}$ After obtaining informed consent, the probands and their biological parents and full siblings were measured for weight, height, waist circumference, percent body fat and other anthropometric measurements. Blood samples were also collected. Details about the characteristics of this sample have been recently reported elsewhere. ${ }^{25}$

\section{Phenotypes}

For qualitative traits, we used four overlapping dichotomies of obesity affection status based on measured BMI $\left(\mathrm{BMI} \geq 27,30,35\right.$ and $\left.40 \mathrm{~kg} / \mathrm{m}^{2}\right)$, which was computed by dividing the measured weight in kilograms by the square of measured height in meters $\left(\mathrm{kg} / \mathrm{m}^{2}\right)$. The four thresholds yield 658 (401 independent in 224 sibships), 472 (316 independent in 203 sibships), 282 (215 independent in 163 sibships) and 134 (115 independent in 100 sibships) affected sib pairs, respectively. We defined independent affected sib pairs according to the definition in the GENEHUNTER manual by taking the first affected sib paired with other affected sibs (2nd, 3rd, ...nth affected sib) in the sibship. For analyses of quantitative traits, we used measured BMI, percent fat and waist circumference after controlling the linear effects of age within sex and generation.

\section{Genotyping}

A total of 382 polymorphic microsatellite markers were genotyped by Marshfield Center for Medical Genetics from the Version 11 Weber Screening Set, which has an average marker spacing of $10 \mathrm{~cm}$. Genetic map distances were taken from the Marshfield Database (http://research.marshfield- clinic.org/genetics). All genotypes were checked for Mendelian inheritance using the computer program MERLIN with the '-error' option (v0.9) ${ }^{28}$ and incompatible genotypes were recoded as unknown.

\section{Genome-wide baseline linkage analyses}

The primary methods used for our second-generation genome scan data have been presented recently. ${ }^{25}$ In brief, we used the GENEHUNTER program to perform nonparametric multipoint linkage analyses using four overlapped qualitative phenotypes. ${ }^{29}$ Allele frequencies were computed based on all individuals who provided DNA. We then employed the MERLIN computer program to conduct regression-based quantitative-trait linkage analyses using the standardized residuals of BMI, percent fat (\%fat) and waist circumference after linear correction for age within generation and sex.

\section{Epistatic interaction analyses of qualitative traits}

Two approaches were used to screen for potential epistatic effects on discrete obesity phenotypes. ${ }^{30}$ The first examined correlations between IBD-sharing proportions or linkage statistics (eg NPL score) at unlinked loci among affected sib pairs (ASPs) or families. We calculated pairwise Pearson's correlation coefficients for ASP-specific IBDsharing proportion and family-specific NPL score between unlinked loci selected according to our genome-wide linkage analyses. We computed the multipoint ASP-specific IBD-sharing proportion and family-specific NPL score using GENEHUNTER.

We conducted permutation tests to calculate empirical $P$ values. To eliminate the potential dependence in IBDsharing probability among the ASPs within a single family and control the effect of family size, we permuted the data among independent ASPs for IBD correlation analyses and among the families with the same number of ASPs for NPL correlation analyses. We generated 10000 replicates by permutation. For each replicate, we computed the correlation coefficients among all possible pairwise loci and recorded the maximum correlation score over all the pairwise correlations. We then calculated corrected $P$-value to adjust for multiple comparisons based on the proportion of times that the observed correlation score was equaled or exceeded by the maximal correlation score of each replicate. Details about the application of a permutation test to family and sibling data have been previously reported elsewhere. ${ }^{14}$

The second approach used was conditional linkage analyses as proposed by Cox et al. ${ }^{21}$ We performed conditional analysis only in the regions demonstrating evidence for positive correlations at a corrected $P<0.05$. In the conditional analyses, we used zero-one and proportional weighting schemes to model a positive relationship between loci on different chromosomes. We computed baseline (unconditional) and conditional LOD (logarithm 
of odds) scores using the ALLEGRO computer program $(\mathrm{v} 1.2 \mathrm{c}) .{ }^{31}$ We assessed the significance of the increase in LOD score on the basis of a conservative $\chi^{2}$ test, as proposed by Cox et al. ${ }^{21}$

\section{Epistatic interaction analyses of quantitative traits}

We used two popular approaches, Haseman-Elston (H-E) regression model and variance component analysis, to detect epistatic interactions using quantitative phenotypes of obesity.

We used the new H-E regression model by incorporating epistatic interactions between the loci. ${ }^{30,32,33}$

In this model, the mean-corrected trait product for a sib pair is regressed on the underlying IBD-sharing proportions at different loci as predictors. To account for the dependencies among multiple sib pairs created from the same family, we incorporated the method of generalized estimating equations (GEE) into $\mathrm{H}-\mathrm{E}$ regression analyses using GENMOD procedures in SAS (v8.2).
In variance components analyses, the phenotypic covariance between relatives was modeled in terms of variance component parameters and underlying IBD-sharing probabilities at one or more genetic loci. We examined epistatic interactions by comparing the likelihood of the models with and without epistatic components of variance. We used age, sex and generation as covariates for the obesity quantitative phenotypes and accounted for the ascertainment scheme by the identification of the primary probands. We performed the analyses using the SOLAR computer program (v1.7). ${ }^{34,35}$

\section{Results}

Loci with linkage evidence in genomewide scan

Table 1 lists the loci with an NPL score $\geq 1.85$ and the significance at $P<0.025$ (GENEHUNTER output $P$ ) for a discrete BMI phenotype $\left(\mathrm{BMI} \geq 27,30,35\right.$ and $\left.40 \mathrm{~kg} / \mathrm{m}^{2}\right)$ using GENEHUNTER or with an LOD score $\geq 1.44$ (MERLIN output $P \leq 0.005)$ for a quantitative obesity phenotype

Table 1 Loci with multipoint NPL scores $\geq 1.85$ or LOD $\geq 1.44$

\begin{tabular}{|c|c|c|c|c|c|c|}
\hline Chromosome & Position (cM) & Marker & Score & $P$ & Analysis (statistics) ${ }^{\mathrm{a}}$ & Phenotype $^{\mathrm{b}}$ \\
\hline \multirow[t]{2}{*}{2} & 0 & SRA & 1.46 & 0.0050 & REG (LOD) & Waist, QTL \\
\hline & 38 & D2S1360 & 1.70 & 0.0030 & REG (LOD) & BMI, QTL \\
\hline \multirow[t]{2}{*}{3} & 124 & D3S3045 & 1.88 & 0.0178 & NPL (Z_all) & $\mathrm{BMI} \geq 30 \mathrm{~kg} / \mathrm{m}^{2}$ \\
\hline & 188 & D3S2427 & 1.50 & 0.0050 & REG (LŌD) & BMI, QTL \\
\hline \multirow{3}{*}{7} & 143 & D4S1644 & 1.71 & 0.0020 & REG (LOD) & BMI, QTL \\
\hline & 109 & D7S821 & 1.93 & 0.0077 & NPL (Z_all) & $\mathrm{BMI} \geq 35 \mathrm{~kg} / \mathrm{m}^{2}$ \\
\hline & 114 & D7S1799 & 2.25 & 0.0024 & NPL (Z_all) & $\mathrm{BMI} \geq 35 \mathrm{~kg} / \mathrm{m}^{2}$ \\
\hline 8 & 94 & D8S2324 & 1.90 & 0.0083 & NPL (Z_all) & $\mathrm{BMI} \geq 35 \mathrm{~kg} / \mathrm{m}^{2}$ \\
\hline 9 & 104 & D9S910 & 2.09 & 0.0010 & NPL (Z_all) & $\mathrm{BMI} \geq 30 \mathrm{~kg} / \mathrm{m}^{2}$ \\
\hline \multirow[t]{3}{*}{12} & 18 & GATA49D12 & 2.12 & 0.0128 & NPL (Z_all) & $\mathrm{BMI} \geq 27 \mathrm{~kg} / \mathrm{m}^{2}$ \\
\hline & 109 & PAH & 1.92 & 0.0151 & NPL (Z_all) & $\mathrm{BMI} \geq 30 \mathrm{~kg} / \mathrm{m}^{2}$ \\
\hline & 125 & D12S2070 & 3.79 & $<0.0001$ & REG (LŌD) & \%fat, QTL \\
\hline \multirow[t]{6}{*}{13} & 26 & D13S1493 & 2.03 & 0.0215 & NPL (Z_all) & $\mathrm{BMI} \geq 40 \mathrm{~kg} / \mathrm{m}^{2}$ \\
\hline & 33 & D13S894 & 2.63 & 0.0043 & NPL (Z_all) & $\mathrm{BMI} \geq 40 \mathrm{~kg} / \mathrm{m}^{2}$ \\
\hline & 47 & D13S1807 & 2.67 & 0.0002 & REG (LŌD) & $\mathrm{BMI}, \mathrm{QTL}$ \\
\hline & 55 & D13S800 & 2.70 & 0.0002 & REG (LOD) & BMI, QTL \\
\hline & 76 & D13S793 & 2.78 & 0.0002 & REG (LOD) & BMI, QTL \\
\hline & 83 & D13S779 & 2.82 & 0.0002 & REG (LOD) & BMI, QTL \\
\hline 21 & 58 & D21S1446 & 4.27 & $<0.0001$ & REG (LOD) & \%fat, QTL \\
\hline
\end{tabular}

aREG: family regression performed in MERLIN; NPL: nonparametric linkage analysis performed in GENEHUNTER; LOD: logarithm of odds; Z all: $Z$ statistic in GENEHUNTER.

BMI: body mass index; Waist: waist circumference; \%fat: percent fat; QTL: quantitative trait locus.

Table 2 Marker pairs with significant $(P \leq 0.05)$ correlations after correction for multiple testing

\begin{tabular}{|c|c|c|c|c|c|c|}
\hline Markers (cM) & $R$ & $N^{a}$ & Empirical $P$ & Corrected $P$ & Phenotypes & Correlation \\
\hline $\begin{array}{l}\text { D2S1360 (38)/D13S1493 (26) } \\
\text { D2S1360 (38)/D13S1493 (26) } \\
\text { D2S1360 (38)/D13S1493 (26) } \\
\text { D2S1360 (38)/D13S894 (33) } \\
\text { D2S1360 (38)/D13S894 (33) }\end{array}$ & $\begin{array}{l}0.272 \\
0.426 \\
0.410 \\
0.357 \\
0.341\end{array}$ & $\begin{array}{r}161 \\
98 \\
102 \\
98 \\
102\end{array}$ & $\begin{array}{l}0.0003 \\
0.0000 \\
0.0000 \\
0.0004 \\
0.0003\end{array}$ & $\begin{array}{l}0.0386 \\
0.0016 \\
0.0023 \\
0.0251 \\
0.0347\end{array}$ & 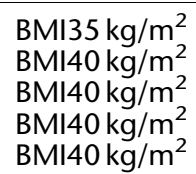 & $\begin{array}{l}\text { NPL } \\
\text { NPL } \\
\text { IBD } \\
\text { NPL } \\
\text { IBD }\end{array}$ \\
\hline
\end{tabular}

\footnotetext{
${ }^{a}$ Number of families for NPL-based analysis and affected sib pairs for IBD-based analysis.
} 
(BMI, percent fat, waist circumference) using the MERLIN program in our initial analysis of genome scan. ${ }^{25}$ We used the criteria to include the loci with marginal linkage evidence in the analysis of qualitative or quantitative traits.

\section{IBD and NPL-based correlation analyses}

To detect dependence between obesity-linked loci, we computed pairwise correlation between the markers on different chromosomes. Table 2 includes IBD and NPLbased correlation scores between the marker pairs with corrected significance levels of $P<0.05$. For NPL-based correlation analyses, the observed highest correlations occurred between D2S1360 (38 cM) and D13S1493 $(26 \mathrm{~cm})$, with a maximal correlation score of 0.272 (empirical $P=0.0003$, corrected $P=0.0386$ ) and 0.426 (empirical $P<0.0001$, corrected $P=0.0016$ ) for $\mathrm{BMI} \geq 35$ and $\geq 40 \mathrm{~kg} / \mathrm{m}^{2}$, respectively. For IBD-sharing proportionbased analyses, the strongest correlation was detected between D2S1360 (38 cM) and D13S1493 (26 cM), with a correlation score of 0.410 (empirical $P<0.0001$, corrected $P=0.0023)$, whereas the correlations approached zero for both unaffected sib pairs (BMI $<27 \mathrm{~kg} / \mathrm{m}^{2}, N=71, r=0.044$, $P=0.7152)$ and discordant sib pairs $\left(\mathrm{BMI}<27 \mathrm{~kg} / \mathrm{m}^{2}\right.$ and $\left.\mathrm{BMI} \geq 40 \mathrm{~kg} / \mathrm{m}^{2}, N=434, r=0.056, P=0.2460\right)$. The strongest and most consistent interactions were for chromosome $2(18-38 \mathrm{~cm})$ and chromosome $13(26-47 \mathrm{~cm})$. In the remaining analyses, we focused on this interaction, since the permutation test and associated correction for multiple testing should be most valid for the highest correlation.

\section{Conditional linkage analyses}

The results of conditional linkage analyses are summarized in Table 3 . The LOD scores at $2 p$ markers $(18-38 \mathrm{~cm})$ increased from 0.06 to 2.06 for $\mathrm{BMI} \geq 30 \mathrm{~kg} / \mathrm{m}^{2}$, from 0.07 to 2.12 for $\mathrm{BMI} \geq 35 \mathrm{~kg} / \mathrm{m}^{2}$ (Figure $1 \mathrm{a}$ ) and from -0.17 to 1.96 for $\mathrm{BMI} \geq 40 \mathrm{~kg} / \mathrm{m}^{2}$ when conditioned on the linkage evidence at D13S1493 $(26 \mathrm{~cm})$. The LOD scores at $13 \mathrm{q}$ markers $(26-33 \mathrm{~cm})$ increased from 0.50 to 2.95 for $\mathrm{BMI} \geq 30 \mathrm{~kg} / \mathrm{m}^{2}$, from 0.85 to 3.11 for $\mathrm{BMI} \geq 35 \mathrm{~kg} / \mathrm{m}^{2}$ and from 1.04 to 4.54 for $\mathrm{BMI} \geq 40 \mathrm{~kg} / \mathrm{m}^{2}$ when conditioned on the linkage evidence at $2 \mathrm{p}$ markers $(18-38 \mathrm{~cm})$.

\section{H-E multiple-regression and variance component analyses}

We further conducted $\mathrm{H}-\mathrm{E}$ multiple-regression and variance component analyses to examine epistatic effects between $2 \mathrm{p}$ markers $(18-38 \mathrm{~cm})$ and $13 \mathrm{q}$ markers (26$47 \mathrm{~cm}$ ) using quantitative traits. Table 4 gives the interaction effects for an epistatic model between the two regions with the significance at $P<0.05$ in $\mathrm{H}-\mathrm{E}$ regression analyses. The observed interaction effects were significant at $P=0.0003$ (GEE $P=0.0012$ ) for BMI, $P=0.0136$ (GEE $P=0.0265$ ) for \%fat, and $P=0.0012$ (GEE $P=0.0023$ ) for waist circumference. Figure $1 b$ shows the LOD scores for markers across chromosome 2 based on a two-locus model
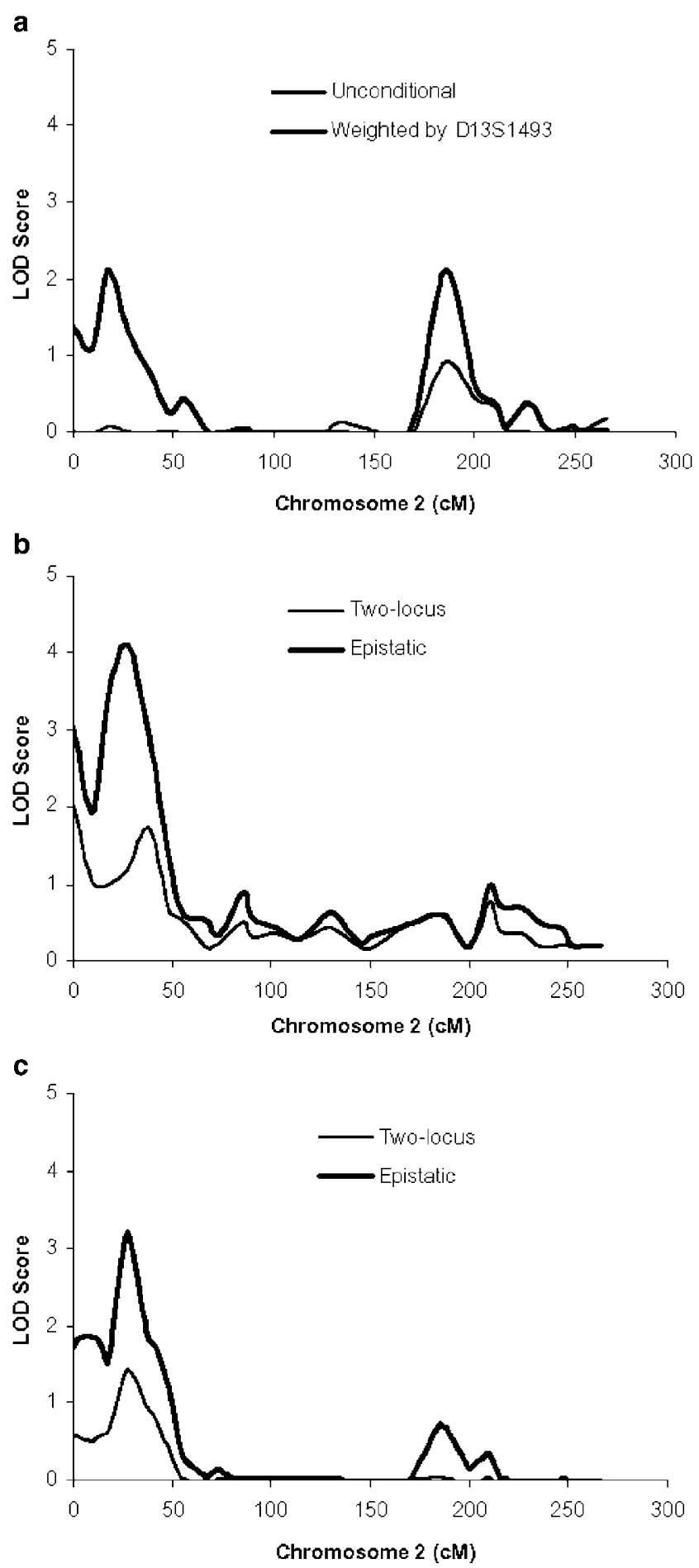

Figure 1 (a) Conditional allele-sharing multipoint analyses of chromosome 2 for $\mathrm{BMI} \geq 35$, weighting families based on evidence for linkage at D13S1493 (26 cM). (b) Analysis of epistatic interaction between D13S1493 (26 cM) and markers on chromosome 2 for BMI using an $\mathrm{H}-\mathrm{E}$ regression model. (c) Analysis of epistatic interaction between D13S1807 (47 cM) and markers on chromosome 2 for BMI using a variance components model. 
Table 3 Epistatic effects for discrete phenotypes based on conditional linkage analysis

\begin{tabular}{|c|c|c|c|c|c|c|c|}
\hline Detected marker (cM) & Conditional marker (cM) & Phenotype & Baseline $L O D$ & Conditional $L O D$ & Weighting scheme & $\chi^{2}$ & $P$ \\
\hline \multirow[t]{2}{*}{ D2S2952 (18) } & D13S1493 (26) & BMI30 kg/m² & 0.06 & 1.93 & $0-1$ & 8.64 & 0.0033 \\
\hline & & & 0.06 & 2.06 & Prop & 9.24 & 0.0024 \\
\hline \multirow[t]{2}{*}{ D2S2952 (18) } & D13S1493 (26) & BMI35 kg/m² & 0.07 & 2.12 & $0-1$ & 9.47 & 0.0021 \\
\hline & & & 0.07 & 1.89 & Prop & 8.40 & 0.0038 \\
\hline \multirow[t]{2}{*}{ D2S1360 (38) } & D13S1493 (26) & $\mathrm{BMI} 40 \mathrm{~kg} / \mathrm{m}^{2}$ & -0.17 & 1.00 & $0-1$ & 5.39 & 0.0202 \\
\hline & & & -0.17 & 1.96 & Prop & 9.78 & 0.0018 \\
\hline \multirow{2}{*}{ D13S894 (33) } & D2S2952 (18) & $\mathrm{BMI} 30 \mathrm{~kg} / \mathrm{m}^{2}$ & 0.50 & 2.95 & $0-1$ & 11.25 & 0.0008 \\
\hline & & & 0.50 & 2.89 & Prop & 11.00 & 0.0009 \\
\hline \multirow{2}{*}{ D13S894 (33) } & D2S2952 (18) & BMI35 kg/m² & 0.85 & 3.11 & $0-1$ & 10.44 & 0.0012 \\
\hline & & & 0.85 & 2.60 & Prop & 8.06 & 0.0045 \\
\hline \multirow{2}{*}{ D13S1493 (26) } & $\mathrm{D} 2 \mathrm{~S} 1360(38)$ & $\mathrm{BMI} 40 \mathrm{~kg} / \mathrm{m}^{2}$ & 1.04 & 4.24 & $0-1$ & 14.74 & 0.0001 \\
\hline & & & 1.04 & 4.54 & Prop & 16.13 & $<0.0001$ \\
\hline
\end{tabular}

Table 4 Epistatic effects based on H-E regression analyses of quantitative phenotypes

\begin{tabular}{|c|c|c|c|c|c|c|c|}
\hline \multirow[b]{2}{*}{ Phenotype } & \multirow[b]{2}{*}{ Marker } & \multicolumn{3}{|c|}{ Two-locus model ${ }^{a}$} & \multicolumn{3}{|c|}{ Epistatic model ${ }^{b}$} \\
\hline & & $\chi^{2}$ & $P$ & GEE $P$ & $\chi^{2}$ & $P$ & GEE P \\
\hline $\begin{array}{l}\mathrm{BMI} \\
(N=1157)\end{array}$ & $\begin{array}{l}\text { D2S1400 } \\
\text { D13S1493 } \\
\text { D2S1400*D13S1493 }\end{array}$ & $\begin{array}{l}4.46 \\
0.75\end{array}$ & $\begin{array}{l}0.0347 \\
0.3872\end{array}$ & $\begin{array}{l}0.068 \\
0.3534\end{array}$ & $\begin{array}{r}3.15 \\
6.23 \\
12.86\end{array}$ & $\begin{array}{l}0.0760 \\
0.0125 \\
0.0003\end{array}$ & $\begin{array}{l}0.0905 \\
0.0075 \\
0.0012\end{array}$ \\
\hline $\begin{array}{l}\% \text { fat } \\
(N=860)\end{array}$ & $\begin{array}{l}\text { D2S2952 } \\
\text { D13S1493 } \\
\text { D2S2952*D13S1493 }\end{array}$ & $\begin{array}{l}2.59 \\
0.21\end{array}$ & $\begin{array}{l}0.1072 \\
0.6448\end{array}$ & $\begin{array}{l}0.1999 \\
0.6552\end{array}$ & $\begin{array}{l}1.21 \\
3.25 \\
6.09\end{array}$ & $\begin{array}{l}0.2704 \\
0.0715 \\
0.0136\end{array}$ & $\begin{array}{l}0.3745 \\
0.0988 \\
0.0265\end{array}$ \\
\hline $\begin{array}{l}\text { Waist } \\
(N=996)\end{array}$ & $\begin{array}{l}\text { D2S2952 } \\
\text { D13S1493 } \\
\text { D2S2952*D13S1493 }\end{array}$ & $\begin{array}{l}1.47 \\
0.26\end{array}$ & $\begin{array}{l}0.2250 \\
0.6082\end{array}$ & $\begin{array}{l}0.2888 \\
0.5629\end{array}$ & $\begin{array}{r}3.86 \\
5.64 \\
10.46\end{array}$ & $\begin{array}{l}0.0495 \\
0.0176 \\
0.0012\end{array}$ & $\begin{array}{l}0.0886 \\
0.0093 \\
0.0023\end{array}$ \\
\hline
\end{tabular}

a Multpile-regression did not include interaction term of the markers.

${ }^{b}$ Multpile-regression included interaction term of the markers.

(chromosome 2 marker and D13S1493) and an epistatic two-locus model (chromosome 2 marker, D13S1493 and their interaction term) in $\mathrm{H}$-E multiple-regression analysis. Similarly, compared with results from an independent twolocus model, LOD scores for the epistatic model increased for BMI at $2 \mathrm{p}(28 \mathrm{~cm}, P=0.0043$, Figure $1 \mathrm{c})$ when conditioned on $13 \mathrm{q}$ marker $(47 \mathrm{~cm})$ in variance component analysis.

\section{Discussion}

Obesity-susceptibility loci in chromosome regions 2p25p24 and 13q13-q21 appear to interact in influencing the development of extreme obesity in European Americans. The evidence was consistent across phenotypes and analytic approaches. For discrete traits, correlations based on IBD and NPL scores were significant after correction for multiple tests, whereas correlations between the two regions approached zero for both concordant unaffected sib pairs and discordant sib pairs. Conditional LOD scores at $13 \mathrm{q}(26-33 \mathrm{cM})$, compared with the baseline, increased by more than 2.2 for all obesity thresholds when conditioned on evidence for linkage at $2 p(18-38 \mathrm{cM})$. Analyses of quantitative traits using $\mathrm{H}-\mathrm{E}$ regression and variance component models also provided strong and consistent support for an interaction.

Multiple testing is a major issue in analyses of gene-gene interactions. In four ways, we attempted to limit untoward effects of the many possible tests in a genome scan while preserving power. First, we limited our focus to regions that reached at least marginal significance in a genome scan. Second, we used permutation tests to estimate empirical significance of individual results. Third, we controlled for multiple testing in the initial correlation analyses. Fourth, we focused extensive analyses only on the strongest and most consistent result from the initial analyses of genegene interactions, that between regions of chromosomes 2 and 13 .

Several groups have reported linkage in the region of chromosome 2 (2p25-p24) which we detected in our recent genome scan (Li et $\left.a l^{25}\right){ }^{36-38}$ There are a very large number 
of genes in the 2p25-p24, but a few are plausible candidate genes that previously have been associated with obesity. For example, ACP1 (acid phosphatase 1 gene, 2p25) is a highly polymorphic enzyme involved in the modulation of signal transduction by insulin. Its six genotypes have substantial variation in total enzymatic activity. Linkages and associations of ACP1 with BMI and obesity-related phenotypes have been reported in several independent studies. ${ }^{39-42}$ Another candidate gene, APO-B (apolipoprotein B, 2p24-p23), has been associated with BMI and \%fat. ${ }^{43-45}$ POMC (pro-opio-melanocortin) is another obesity-associated gene that lies within $13 \mathrm{~cm}$ of our peak marker (D2S1360, 38 cM) on 2p15. Other plausible candidates have been found using animal models, including SDC1 (syndecan-1) ${ }^{46}$ and LIPIN. ${ }^{47}$

Evidence for the presence of linkage between obesity traits and markers on 13q14-21 has been reported in several independent studies. Feitosa et $a l^{48}$ detected evidence for linkage with BMI on 13q14 marker D13S257 in a combined sample of 401 three-generation families. ${ }^{48} \mathrm{~A}$ genome-wide scan in the Quebec Family Study also reported a linkage between abdominal subcutaneous fat and D13S325 (47 cM, 13q14). ${ }^{49}$ Knoblauch et al ${ }^{50}$ detected evidence for linkage between 13q21 (the second peak on chromosome 13 in our study, Table 1$)$ and BMI $(P<0.0001)$ in a DZ twin sample. One plausible candidate gene from this region of chromosome 13 is 5-hydroxytryptamine (serotonin) receptor gene $\left(5-\mathrm{HTR}_{2 \mathrm{~A}}\right)$, which is located at 13q14-q21 and has been reported to be associated with obesity. Serotonin is an important mediator in the control of satiety mechanisms. Serotonin reduces food intake and is probably involved in weight regulation. ${ }^{51} \mathrm{~A}$ polymorphism in 5-HT2A receptor gene promoter has been reported to be associated with abdominal obesity. ${ }^{52} \mathrm{~A}$ polymorphism in $5-\mathrm{HTR}_{2 \mathrm{~A}}$ has also been shown to be associated with dietary energy and alcohol intake in obese people. ${ }^{53}$

It is possible that several genes in chromosome regions 2p25-24 and 13q13-21, including but not limited to those listed above, could interact to influence the development of obesity. As the observed interactions are at a statistical (rather than biological) level, further and independent studies are needed to confirm and refine the observed results. While it will not be easy or even straightforward to identify the specific interactions at a molecular level, the knowledge that a statistical interaction exists should prove useful and could even turn out to be crucial to the identification of specific gene polymorphisms having relatively subtle effects on obesity phenotypes. ${ }^{21,54}$

\section{Summary}

The present study provides statistical evidence that genetic loci in chromosome regions 2p25-p24 and 13q13-21 may interact to influence the development of human obesity.
Further study and independent replications are needed to confirm and refine the observed results. The identification of gene interactions may be crucial to understand the roles played by specific gene polymorphisms in complex traits such as obesity.

\section{Acknowledgements}

This research was supported in part by National Institute of Health grants R01DK44073, R01DK48095 and R01DK56210 to RAP. Genotypes were completed by the NHLBI supported Marshfield Genotyping Service. We gratefully acknowledge the generous cooperation of participating families. We thank Ms Elizabeth Joe, Ms Carmeron Braswell, Ms Quan Cao, Dr Balasahib Shinde, Mr Jeffrey Hannah, Ms Jan Merideth and Ms Kye Yun for technical assistance.

\section{References}

1 Price RA: Genetics and common obesities: background, current status, strategies and future prespects; in Wadden TS (ed): Obesity, theory and therapy. New York: Guilford Publications, 2001.

2 Shmulewitz D, Auerbach SB, Lehner T et al: Epidemiology and factor analysis of obesity, type II diabetes, hypertension, and dyslipidemia (syndrome $\mathrm{X}$ ) on the Island of Kosrae, Federated States of Micronesia. Hum Hered 2001; 51: 8-19.

3 Kopelman PG: Obesity as a medical problem. Nature 2000; 404: $635-643$.

4 Wolk A, Gridley G, Svensson M et al: A prospective study of obesity and cancer risk (Sweden). Cancer Causes Control 2001; 12: $13-21$.

5 Carroll KK: Obesity as a risk factor for certain types of cancer. Lipids 1998; 33: 1055-1059.

6 Maes HH, Neale MC, Eaves LJ: Genetic and environmental factors in relative body weight and human adiposity. Behav Genet 1997; 27: $325-351$.

7 Grilo CM, Pogue-Geile MF: The nature of environmental influences on weight and obesity: a behavior genetic analysis. Psychol Bull 1991; 110: 520-537.

8 Price RA, Gottesman II: Body fat in identical twins reared apart: roles for genes and environment. Behav Genet 1991; 21: 1-7.

9 Stunkard AJ, Harris JR, Pedersen NL, McClearn GE: The bodymass index of twins who have been reared apart. $N$ Engl J Med 1990; 322: 1483-1487.

10 Sorensen TI, Price RA, Stunkard AJ, Schulsinger F: Genetics of obesity in adult adoptees and their biological siblings. Br Med J 1989; 298: 87-90.

11 Price RA: Genetics of human obesity. Ann Behav Med 1987; 9: $9-14$.

12 Stunkard AJ, Sorensen TI, Hanis C et al: An adoption study of human obesity. N Engl J Med 1986; 314: 193-198.

13 Segal NL, Allison DB: Twins and virtual twins: bases of relative body weight revisited. Int J Obes Relat Metab Disord 2002; 26: 437-441.

14 Dong C, Wang S, Li WD, Li D, Zhao H, Price RA: Interacting genetic loci on chromosomes 20 and 10 influence extreme human obesity. Am J Hum Genet 2003; 72: 115-124.

15 Snyder EE, Walts B, Perusse L et al: The human obesity gene map: the 2003 update. Obes Res 2004; 12: 369-439.

16 Price RA: Genetics and common obesities: background, current status, strategies and future prospects. New York: Cuilford Publications, 2002.

17 Ollmann MM, Wilson BD, Yang YK et al: Antagonism of central melanocortin receptors in vitro and in vivo by agouti-related protein. Science 1997; 278: 135-138. 
18 Niswender KD, Morton GJ, Stearns WH, Rhodes CJ, Myers Jr MG, Schwartz MW: Intracellular signaling. Key enzyme in leptininduced anorexia. Nature 2001; 413: 794-795.

19 Warden $\mathrm{CH}$, Yi N, Fisler J: Epistasis among genes is a universal phenomenon in obesity: evidence from rodent models. Nutrition 2004; 20: 74-77.

20 Spiegelman BM, Flier JS: Obesity and the regulation of energy balance. Cell 2001; 104: 531-543.

21 Cox NJ, Frigge M, Nicolae DL et al: Loci on chromosomes 2 (NIDDM1) and 15 interact to increase susceptibility to diabetes in Mexican Americans. Nat Genet 1999; 21: 213-215.

$22 \mathrm{Xu} \mathrm{J}$, Meyers DA, Ober C et al: Genomewide screen and identification of gene-gene interactions for asthmasusceptibility loci in three US populations: collaborative study on the genetics of asthma. Am J Hum Genet 2001; 68: 1437-1446.

23 Capon F, Semprini S, Dallapiccola B, Novelli G: Evidence for interaction between psoriasis-susceptibility loci on chromosomes 6p21 and 1q21. Am J Hum Genet 1999; 65: 1798-1800.

24 Gray-McGuire C, Moser KL, Gaffney PM et al: Genome scan of human systemic lupus erythematosus by regression modeling: evidence of linkage and epistasis at 4p16-15.2. Am J Hum Genet 2000; 67: 1460-1469.

25 Li WD, Dong C, Li D, Zhao H, Price RA: An obesity related-locus in chromosome region 12q23-24. Diabetes 2004; 53: 812-820.

26 Lee JH, Reed DR, Li WD et al: Genome scan for human obesity and linkage to markers in 20q13. Am J Hum Genet 1999; 64: 196-209.

27 Price RA, Reed DR, Lee JH: Obesity related phenotypes in families selected for extreme obesity and leanness. Int J Obes Relat Metab Disord 1998; 22: 406-413.

28 Abecasis GR, Cherny SS, Cookson WO, Cardon LR: Merlin - rapid analysis of dense genetic maps using sparse gene flow trees. Nat Genet 2002; 30: 97-101.

29 Kruglyak L, Daly MJ, Reeve-Daly MP, Lander ES: Parametric and nonparametric linkage analysis: a unified multipoint approach. Am J Hum Genet 1996; 58: 1347-1363.

30 Cordell HJ: Epistasis: what it means, what it doesn't mean, and statistical methods to detect it in humans. Hum Mol Genet 2002; 11: $2463-2468$

31 Gudbjartsson DF, Jonasson K, Frigge ML, Kong A: Allegro, a new computer program for multipoint linkage analysis. Nat Genet 2000; 25: 12-13.

32 Elston RC, Buxbaum S, Jacobs KB, Olson JM: Haseman and Elston revisited. Genet Epidemiol 2000; 19: 1-17.

33 Allison DB, Fernandez JR, Heo M, Beasley TM: Testing the robustness of the new Haseman-Elston quantitative-trait locimapping procedure. Am J Hum Genet 2000; 67: 249-252.

34 Blangero J, Williams JT, Almasy L: Robust LOD scores for variance component-based linkage analysis. Genet Epidemiol 2000; 19: S8-S14.

35 Almasy L, Blangero J: Multipoint quantitative-trait linkage analysis in general pedigrees. Am J Hum Genet 1998; 62: $1198-1211$.

36 Aouizerat BE, Allayee H, Cantor RM et al: A genome scan for familial combined hyperlipidemia reveals evidence of linkage with a locus on chromosome 11. Am J Hum Genet 1999; 65: $397-412$.

37 Pajukanta P, Allayee H, Krass KL et al: Combined analysis of genome scans of Dutch and Finnish families reveals a susceptibility locus for high-density lipoprotein cholesterol on chromosome 16q. Am J Hum Genet 2003; 72: 903-917.
38 Soro A, Pajukanta P, Lilja HE et al: Genome scans provide evidence for low-HDL-C loci on chromosomes 8q23, 16q24.124.2, and 20q13.11 in Finnish families. Am J Hum Genet 2002; 70: $1333-1340$.

39 Lucarini N, Antonacci E, Bottini N, Gloria Bottini F: Lowmolecular-weight acid phosphatase (ACP1), obesity, and blood lipid levels in subjects with non-insulin-dependent diabetes mellitus. Hum Biol 1997; 69: 509-515.

40 Lucarini N, Finocchi G, Gloria-Bottini F et al: A possible genetic component of obesity in childhood. Observations on acid phosphatase polymorphism. Experientia 1990; 46: 90-91.

41 Bottini N, MacMurray J, Peters W, Rostamkhani M, Comings DE: Association of the acid phosphatase (ACP1) gene with triglyceride levels in obese women. Mol Genet Metab 2002; 77: 226-229.

42 Greene LS, Bottini N, Borgiani P, Gloria-Bottini F: Acid phosphatase locus 1 (ACP1): possible relationship of allelic variation to body size and human population adaptation to thermal stress - a theoretical perspective. Am J Human Biol 2000; 12: $688-701$.

43 Rajput-Williams J, Knott TJ, Wallis SC et al: Variation of apolipoprotein-B gene is associated with obesity, high blood cholesterol levels, and increased risk of coronary heart disease. Lancet 1988; 2: 1442-1446.

44 Saha N, Tay JS, Heng CK, Humphries SE: DNA polymorphisms of the apolipoprotein $\mathrm{B}$ gene are associated with obesity and serum lipids in healthy Indians in Singapore. Clin Genet 1993; 44: 113-120.

45 Pouliot MC, Despres JP, Dionne FT et al: ApoB-100 gene EcoRI polymorphism. Relations to plasma lipoprotein changes associated with abdominal visceral obesity. Arterioscler Thromb 1994; 14: 527-533.

46 Reizes $\mathrm{O}$, Lincecum J, Wang $\mathrm{Z}$ et al: Transgenic expression of syndecan-1 uncovers a physiological control of feeding behavior by syndecan-3. Cell 2001; 106: 105-116.

47 Peterfy M, Phan J, Xu P, Reue K: Lipodystrophy in the fld mouse results from mutation of a new gene encoding a nuclear protein, lipin. Nat Genet 2001; 27: 121-124.

48 Feitosa MF, Borecki IB, Rich SS et al: Quantitative-trait loci influencing body-mass index reside on chromosomes 7 and 13: the National Heart, Lung, and Blood Institute Family Heart Study. Am J Hum Genet 2002; 70: 72-82.

49 Perusse L, Rice T, Chagnon YC et al: A genome-wide scan for abdominal fat assessed by computed tomography in the Quebec Family Study. Diabetes 2001; 50: 614-621.

50 Knoblauch H, Muller-Myhsok B, Busjahn A et al: A cholesterollowering gene maps to chromosome 13q. Am J Hum Genet 2000; 66: $157-166$

51 Leibowitz SF, Weiss GF, Suh JS: Medial hypothalamic nuclei mediate serotonin's inhibitory effect on feeding behavior. Pharmacol Biochem Behav 1990; 37: 735-742.

52 Rosmond R, Bouchard C, Bjorntorp P: 5-HT2A receptor gene promoter polymorphism in relation to abdominal obesity and cortisol. Obes Res 2002; 10: 585-589.

53 Aubert R, Betoulle D, Herbeth B, Siest G, Fumeron F: 5-HT2A receptor gene polymorphism is associated with food and alcohol intake in obese people. Int J Obes Relat Metab Disord 2000; 24: 920-924.

54 Horikawa Y, Oda N, Cox NJ et al: Genetic variation in the gene encoding calpain-10 is associated with type 2 diabetes mellitus. Nat Genet 2000; 26: 163-175. 